\title{
Ueber Keuchhustenserum.
}

Erwiderung auf die Veröffentlichung von Dr. Martha Bardach in Nr. 30. Von Dr. Georg Stern, Oberarzt der Klinik.

Ich muß es mir versagen, die Tonart, welche Fräulein Bar. dach in ihrer Veröffentlichıng "Ueber Keuchhustenserum" anzuschlageı beliebt, nachzuahmen.

Was die verschiedenen sachlich unrichtigen Bemerkungen Bar. dachs betrifft, so möchte ich hier nur folgendes hervorheben: Die Kenntuis voll den Versuchen Violis hatte ich bereits lange vor der öffentlichen Vorlesung Lades aus einein Aufsatz Lederers im Arch. f. Kindhlk. 66 und ebenso die Absicht, sie 11 achzuprüfen. Die genannte Vorlesung selbst war für mich nur das a ıs lösende Moment, nach clerselben in Gespräch mit Bardach und Lade auf die Lederersche Arbeit vou mir a us hinzuweisen. Wenn ich mich recht entsinne, hatte sie außer mir nur Lade gelesen, ohne sich aber der betreffenden Zeitschrift zul erinnerı. Ich war es, der dann aus eigener Initiative herans einen Brief an das Kölner Zentralimpfinstitut mit der Bitte um Serumherstellung richtete und diesen Brief $\mathrm{Lad} \epsilon$ als Oberarzt der Infektionsklinik zur Unterschrift vorlegte. Bei meinen Weggang von der Klinik war noch nie irgendeine Seruminjektion eines keuchhustenkranken Kindes vorgenommen worden. Somit bestand für mich nicht die geringste Veranlassung, auf die bisherigen Unterhaltungen über die vermutliche Wirkung iil meinem Aufsatz einzugehen.

Voıı den Versıchen mit dem auf meine Veranlassung aus Kölı bezogenen Serum, die Bardach und v. Gottberg kurz nach meinen Weggang von Düsseldorf vornahmen, hatte ich bishe $1^{\prime}$ keine Kenntnis. Von irgendeiner Benachrichtigung meinerseits hat man abgesehen, trotzdem man sich, wie Bardach schreibt, meiner Mithilfe bedienen wollte!

Ich selbst nahm erst fast ein Jahr später - i in letzteu Winter, als also die ergebnislosen, bisher unveröffentlichten Versuche Bardachs und v. Gotthergs anscheinend schon lällgst wieder a ufgegeben wordell waren - gemeinsam mit Schnbert die Nachprüfung der Violischen Methode hier in Rostock wieder auf.

Unseıe Versıche unterscheiden sich allerdings dadurch von denen aus Düsseldorf, daß wir unsere Tiere selbst vakziniertell ulld unser Serum selbst gewannen, nicht aber von fremder Hand herstellen ließen. Günstige therapeutische Erfolge mit diesem Serum sind uns auch von anderer Seite bestätigt worden.

Jedenfalls dürfte wohl ein jeder - auch Schubert und Stern-das Recht haben, die Violischen Versuche. die für jedermann in einer bekannten kinder. ärztlichen Zeitschrift zugänglich sind, seinerseits ıachzuprüfen, auszubaueı und zu verwenden.

Eine sachliche Kritik solcher Nachprüfungen ist allerdings etwas anderes als die Veröffentlichung von $\mathrm{Bardach}$, die damit für mich abgetan ist ${ }^{1}$ ). 